\title{
Microcirculation during surgery
}

Received January 9, 2022

Revised January 12, 2022

Accepted January 13, 2022

\section{Corresponding author}

Yunseok Jeon, M.D., Ph.D.

Department of Anesthesiology and

Pain Medicine, Seoul National

University Hospital, Seoul National

University College of Medicine, 101

Daehak-ro, Jongno-gu, Seoul 03080,

Korea

Tel: 82-2-2072-3108

Fax: 82-2-747-8363

E-mail: jeonyunseok@gmail.com

\section{Karam Nam and Yunseok Jeon}

Department of Anesthesiology and Pain Medicine, Seoul National University Hospital, Seoul National University College of Medicine, Seoul, Korea

Throughout the long history of surgery, there has been great advancement in the hemodynamic management of surgical patients. Traditionally, hemodynamic management has focused on macrocirculatory monitoring and intervention to maintain appropriate oxygen delivery. However, even after optimization of macro-hemodynamic parameters, microcirculatory dysfunction, which is related to higher postoperative complications, occurs in some patients. Although the clinical significance of microcirculatory dysfunction has been well reported, little is known about interventions to recover microcirculation and prevent microcirculatory dysfunction. This may be at least partly caused by the fact that the feasibility of monitoring tools to evaluate microcirculation is still insufficient for use in routine clinical practice. However, considering recent advancements in these research fields, with more popular use of microcirculation monitoring and more clinical trials, clinicians may better understand and manage microcirculation in surgical patients in the future. In this review, we describe currently available methods for microcirculatory evaluation. The current knowledge on the clinical relevance of microcirculatory alterations has been summarized based on previous studies in various clinical settings. In the latter part, pharmacological and clinical interventions to improve or restore microcirculation are also presented.

Keywords: Hemodynamic monitoring; Intensive care; Microcirculation; Perioperative care; Surgery.

\section{INTRODUCTION}

Oxygen metabolism is essential for living tissue function, and without oxygen, human cells cannot survive. For successful oxygen transport, sufficient oxygenated blood should first be generated, usually from the cardiopulmonary system, and this oxygenated blood should be transported to the tissues and, finally, cells. Microcirculation is the circulation within the microvessels (diameter, $<20 \mu \mathrm{m}$ ) and the final step of oxygen transport to the cell level [1].

Inappropriate oxygen delivery and tissue ischemia are frequent in critically ill patients, including surgical patients [24]. Tissues may recover from ischemia or progress to local- ized necrosis. However, tissue ischemia or cell death itself may aggravate inflammatory reactions and result in necrosis, thus entering a vicious cycle. Therefore, appropriate oxygen transport to tissues is the primary goal for the hemodynamic management of surgical patients.

Traditionally, hemodynamic monitoring and interventions have focused on macrocirculatory parameters, such as cardiac output and blood pressure [5]. However, even with appropriate macrocirculatory parameters, such as sufficient cardiac output and blood pressure, a sufficient amount of oxygen may not reach the tissue and cells with microcirculatory dysfunction [6]. Thus, even if appropriate macrocirculatory parameters are achieved, some patients may experience

This is an Open Access article distributed under the terms of the Creative Commons Attribution Non-Commercial License (http://creativecommons.org/licenses/by-nc/4.0) which permits unrestricted non-commercial use, distribution, and reproduction in any medium, provided the original work is properly cited.

Copyright (C) the Korean Society of Anesthesiologists, 2022 
various ischemic complications, including mortality $[7,8]$.

Considering the lack of monitoring tools and understanding of microcirculation during routine clinical practice, our intervention to augment macrocirculatory parameters may not be helpful for microcirculation but rather may impair microcirculation and aggravate tissue ischemia [9].

\section{EVALUATION OF MICROCIRCULATION}

As the hemodynamic measurement of macrocirculatory parameters, such as blood pressure and cardiac output, is significant during traditional hemodynamic management, it is of particular importance to establish validated, reliable, and practical measurement methods for microcirculation. While abundant knowledge and experience have been collated regarding the measurement of macrocirculatory parameters (e.g., cardiac output and blood pressure) [5], the microcirculatory assessment has not yet been standardized sufficiently to be incorporated into routine clinical practice [10]. Despite this limitation, several noninvasive or minimally invasive tools for microcirculatory evaluation have been developed and are readily available.

\section{Sublingual microscopy}

Microcirculation is generally defined as a complex network of microvessels (usually with a diameter of $<20 \mu \mathrm{m}$ ) consisting of capillaries, arterioles, and venules [11]. Sublingual microscopy enables direct inspection and evaluation of the microvascular network at the bedside [12]. Another notable strength of sublingual microscopy is its noninvasiveness [12].
Since the introduction of handheld vital microscopes (HVMs) in the late 1990s [13], three techniques for sublingual microscopy have been established [14]. First-generation HVMs use an orthogonal polarized spectral imaging technique where cross-polarized green light is emitted to visualize microvasculature and not transilluminate the tissue surface [15]. However, there are several weaknesses in orthogonal polarized spectral imaging HVMs, such as bulkiness and the requirement for high-powered light sources, which limit their application [13]. Second-generation HVMs have been developed to overcome these limitations. These devices adopted a sidestream dark-field imaging technique [16]. The most recently developed devices, third-generation HVMs, use an incident dark-field imaging technique and further improve the image quality of microcirculation [17]. Currently, second- and third-generation HVMs are commercially available.

HVMs usually contain a ring of stroboscopic light-emitting diodes. Light with a wavelength of $530 \mathrm{~nm}$ is absorbed by hemoglobin, thereby helping visualize the microvascular flow of red blood cells (Fig. 1). Microcirculatory images can be obtained by directly applying an HVM to the mucosal membrane in various regions. Several previous studies on microcirculation have predominantly focused on the sublingual mucosa, which is the most commonly selected region for HVMs (Fig. 1) [18]. Studies have also evaluated microcirculation in various organs, such as the lungs [19], liver [20], and brain [21]. However, contrary to the sublingual mucosa, such organs are not always accessible for measurement in most clinical scenarios, except in the surgical setting.

Images obtained using an HVM can be analyzed with (a)

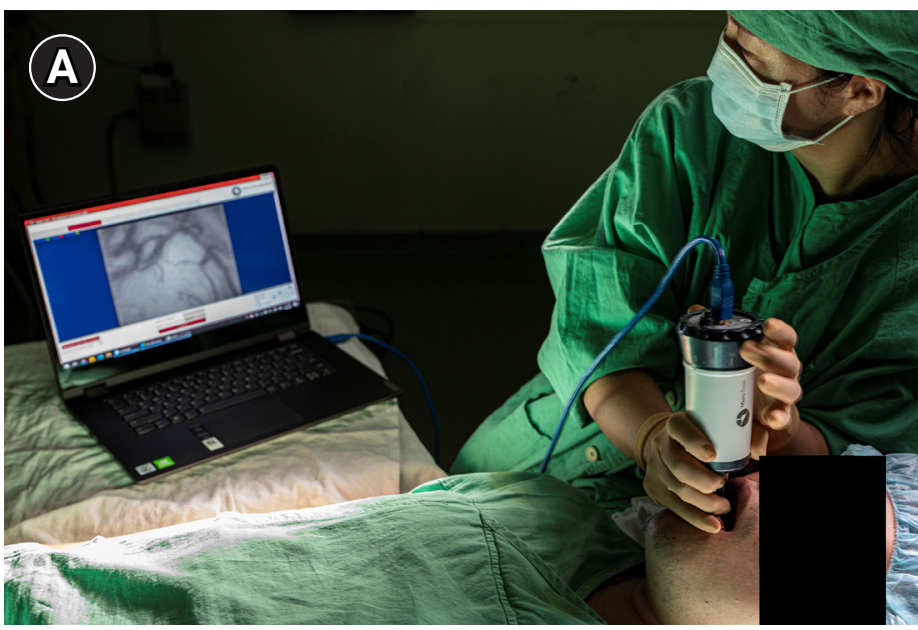

\section{B}

Fig. 1. Direct inspection of microcirculation and video acquisition from the sublingual mucosa (A); images are stored in a computer, which is connected to a handheld vital microscope (B). 
bedside visual assessment [22], (b) the aid of offline software [23], or (c) online automatic software [24,25]. From images obtained using a HVM, two physiological components can be analyzed: convective and diffusive oxygen transport [18]. While the convective property of microcirculation describes the flow of red blood cells in microvessels, the diffusive property refers to the density of perfused microvessels. For the qualification or quantification of these two microcirculatory components, several microcirculatory parameters were recommended in an expert consensus meeting [26]. An update of the expert consensus meeting was published recently [18]. The microcirculatory parameters recommended by the expert consensus are listed and described in Table 1.

However, the application of sublingual microscopy in dai- ly clinical settings outside the research area is currently not recommended $[18,27]$, although it has provided a better understanding of microcirculation to researchers and clinicians.

\section{Vascular occlusion test}

During the vascular occlusion test (VOT), a pneumatic cuff applied on the upper arm is inflated, and after transient ischemia to the arm, it is released [28]. During this procedure, the tissue oxygen saturation sensor on the thenar muscle measures the changes in tissue oxygenation (Fig. 2). Thus, microvascular reactivity can be evaluated by analyzing changes in tissue saturation [29-31]. Among the VOT pa-

Table 1. Microcirculatory Parameters Recommended by the Expert Consensus

\begin{tabular}{|c|c|c|}
\hline Parameters & Definition & Notes \\
\hline Total vessel density (TVD, $\mathrm{mm} / \mathrm{mm}^{2}$ ) & Total vessel area per surface area & $\begin{array}{l}\text { Surrogate for capillary distance (diffusive prop- } \\
\text { erty) }\end{array}$ \\
\hline De Backer score (n/mm) & $\begin{array}{l}\text { The number of vessels crossing a grid (three } \\
\text { horizontal and vertical equidistance lines } \\
\text { drawn on the screen) divided by the total } \\
\text { length of the gridlines }\end{array}$ & $\begin{array}{l}\text { Surrogate for TVD applicable to different vessel } \\
\text { types }\end{array}$ \\
\hline Proportion of perfused vessels (PPV, \%) & $\begin{array}{l}\text { Percentage of perfused vessels per total ves- } \\
\text { sels }\end{array}$ & $\begin{array}{l}\text { Based on binomial determinant of perfusion: } \\
\text { "flow" or "no-flow" (convective property) }\end{array}$ \\
\hline Perfused vessel density (PVD, mm/mm²) & $T V D \times P P V$ & $\begin{array}{l}\text { Determinant of capillary distance (diffusive } \\
\text { property) and red blood cell velocity (convec- } \\
\text { tive property) }\end{array}$ \\
\hline Microvascular flow index (MFI, arbitrary unit) & $\begin{array}{l}\text { Grid-based score per quadrant: } 0 \text {, stop flow; } 1 \text {, } \\
\text { intermittent flow; } 2 \text {, sluggish flow; and 3, nor- } \\
\text { mal flow }\end{array}$ & $\begin{array}{l}\text { Quick, semiquantitative assessment of the red } \\
\text { blood cell velocity by "eyeballing" }\end{array}$ \\
\hline Space-time diagram (STD, mm/s) & Measurement of exact red blood cell velocity & $\begin{array}{l}\text { Determinant of red blood cell velocity (convec- } \\
\text { tive capacity) }\end{array}$ \\
\hline Heterogeneity index (HI, arbitrary unit) & $\begin{array}{l}\text { Coefficient of variation, expressed as (maxi- } \\
\text { mum - minimum value) / average }\end{array}$ & Determinant of heterogeneity of blood flow \\
\hline
\end{tabular}
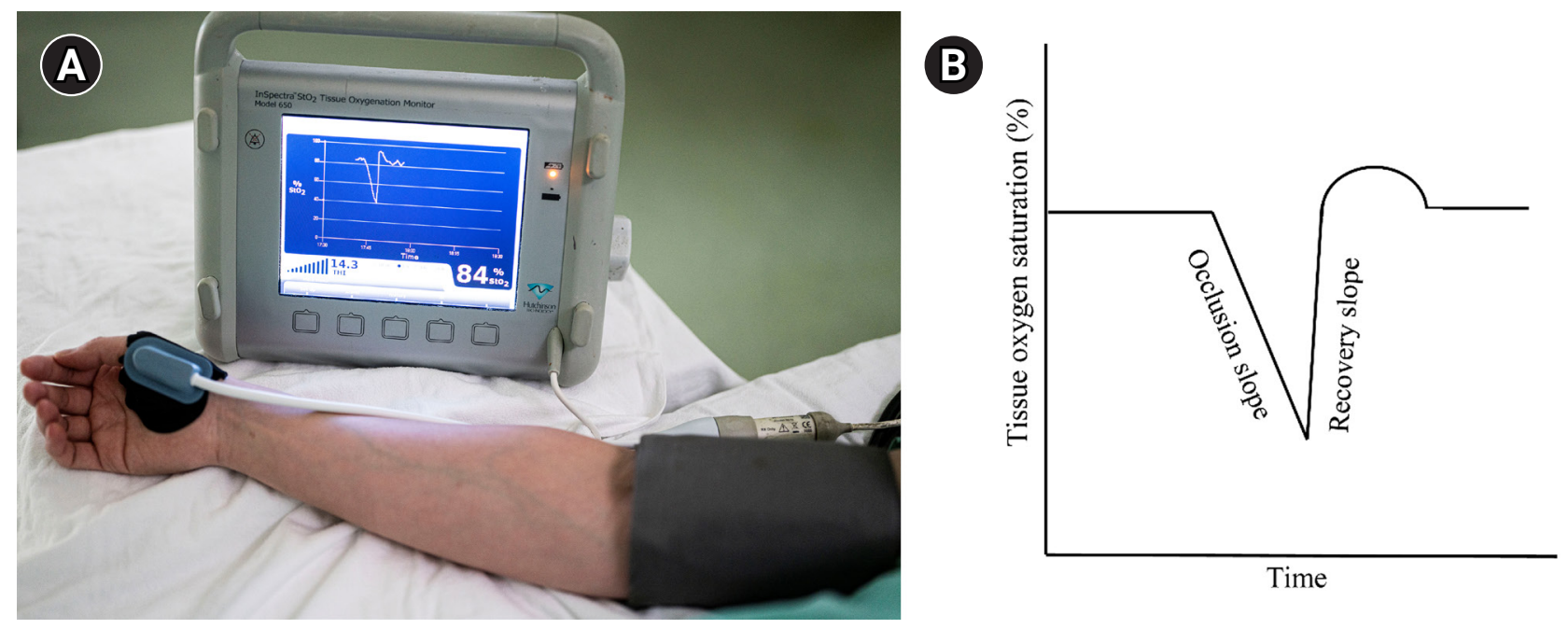

Fig. 2. Vascular occlusion test (A) and a schematic plot of the change in tissue oxygenation (B). 
rameters, the recovery slope has been widely used. The recovery slope of the VOT measures the velocity of tissue oxygen saturation change from the nadir value to its baseline values and has been reported to be related to clinical outcomes in patients with severe sepsis and cardiac surgery [32]. Previously, we reported that the recovery slope decreased during cardiac surgery, and this decrease in recovery slope recovered on the first postoperative day in patients without postoperative complications but not in patients with postoperative complications [33].

\section{Laser Doppler flowmetry}

Microvascular perfusion can be measured not only by HVMs but also by laser Doppler flowmetry (LDF; Fig. 3) at the bedside [34]. As with HVMs, LDF can be applied to all organ surfaces, particularly the skin. The LDF technique quantifies backscattered Doppler-shifted light from the tissue during motion [35]. The backscattered light from each point of the skin was detected separately, thus generating a color-coded two-dimensional image [36,37]. LDF imaging has long been used in both clinical and experimental settings [38-41].

Unfortunately, LDF does not provide absolute microvascular blood flow values in individual vessels or vascular heterogeneity $[7,35]$. Furthermore, the ability to reflect actual microcirculatory alterations, not just changes in regional blood flow, is questionable [42].

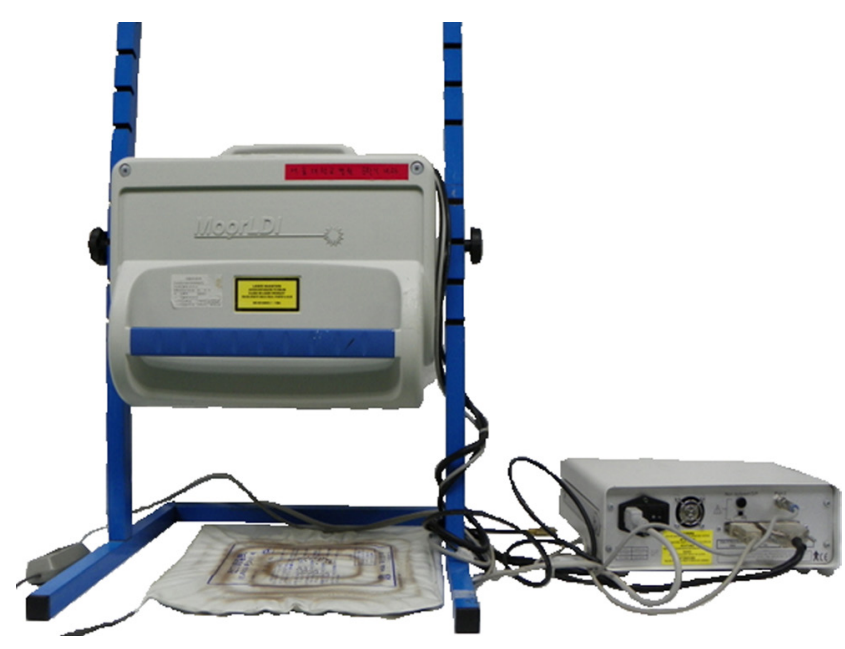

Fig. 3. A laser Doppler flowmetry device (MoorLDI, Moor Instruments Ltd., UK) for microcirculatory evaluation. Visualized objects such as the hand or foot is placed under the imager like X-ray shooting.

\section{Other methods for microcirculatory evaluation}

The evaluation of microcirculation is also possible using near-infrared spectroscopy [31] or with assessment based on the tissue partial pressure of carbon dioxide [43,44], gastric $\mathrm{pH}$ [45], indocyanine green plasma disappearance rate [46], or gastric mucosal-arterial pressure gradient of carbon dioxide [46].

\section{MICROCIRCULATION IN SEPSIS}

Sepsis may be the case in which microcirculation is the most widely studied. In patients with sepsis, microcirculatory dysfunction is observed ahead of the macrocirculatory abnormality [47-49], which is one of the strongest predictors of clinical outcomes. Microcirculatory dysfunction is more severe in nonsurvivors $[47,50]$, and there are also differences in the recovery of microcirculatory dysfunction based on therapeutic interventions between survivors and nonsurvivors [51-53].

Twenty years earlier, goal-directed therapy using macrocirculatory parameters showed strong clinical benefits in patients with sepsis [54] and was subsequently recommended in the guidelines [55]. However, in recent large clinical trials using similar protocols with macrocirculatory parameters, clinical benefits have not been observed [56-59]. If the optimization of macrocirculation reaches certain target values, further clinical benefit may not be possible with usual goal-directed therapy using macrocirculatory parameters without microcirculatory improvement.

\section{MICROCIRCULATION IN NONCARDIAC SURGERY}

In the meta-analysis, microcirculation via sublingual microscopy was impaired during both cardiac and noncardiac surgeries [60]. Several clinical trials have evaluated microcirculation without sublingual microscopy using the gastric $\mathrm{pH}$ [45], LDF technique [61], indocyanine green plasma disappearance rate, and gastric mucosal-arterial pressure gradient of carbon dioxide [46].

Among 25 patients undergoing major abdominal surgery, those with postoperative complications showed higher microvascular dysfunction with impaired sublingual microscopy parameters [62]. However, there were no differences in macrocirculatory parameters, such as cardiac output, blood pressure, oxygen delivery, and lactate levels [62]. Among 31 
general or thoracic surgery patients, postoperative microcirculation dysfunction $1 \mathrm{~h}$ postoperatively via sublingual microscopy was correlated with blood lactate level elevation 24 h postoperatively [63].

\section{MICROCIRCULATION IN CARDIAC SURGERY}

Cardiac surgery is one of the most invasive surgeries that induce a strong inflammatory reaction [64-68]. Moreover, several cardiopulmonary bypass-related factors may affect microcirculation. These include hypothermia [69], non-pulsatile blood flow [70], vasoactive drugs [71], and hemodilution [72]. In addition, heart failure and cardiogenic shock are related to microcirculation dysfunction [73-75]. Although most previous clinical trials enrolled a small number of patients, a certain degree of microcirculatory dysfunction was observed [76-81]. It was also shown that anesthesia itself may induce microcirculatory alterations [77-79,81]. In one study, which included on-pump and off-pump cardiac surgery and thyroid surgery, perfused small vessel density decreased most severely and for the longest duration in onpump cardiac surgery and decreased the least and was transient in thyroid surgery [76]. In another study of cardiac surgery patients, microcirculation was preserved only in those undergoing off-pump cardiac surgery [80].

\section{RELATIONSHIP BETWEEN MICROCIRCULATION AND MACROCIRCULATION}

If there is no cardiac output, microcirculation is not observed. Therefore, a $100 \%$ dissociation between macrocirculation and microcirculation may not be possible. However, in several clinical studies performed under various critical clinical situations, microcirculation parameters showed an independent pattern from macrocirculatory parameters $[6,51,82-84]$.

We also previously showed that among cardiac surgery patients, those with complications showed lower microcirculation function on VOT, but there were no differences in the macrocirculatory parameters [33].

\section{MICROCIRCULATION AND INTERVENTION}

Microcirculation has been observed during various hemo- dynamic and non-hemodynamic interventions.

\section{Vasopressor}

Increasing arterial pressure with the use of conventional vasopressors is not effective in restoring microcirculation but rather may aggravate microcirculation in patients with sepsis or animal models [85-87]. Similarly, for cardiac surgery patients undergoing cardiopulmonary bypass, increasing blood pressure from 47 to $68 \mathrm{mmHg}$ with phenylephrine resulted in a decrease in small vessel blood flow measured using sublingual microscopy [78]. Thus, increasing perfusion pressure with vasopressor use may not improve microcirculation but rather impair it; however, at the same time, it should be considered that increasing perfusion pressure was reported to be beneficial for perfusion of other organs, such as the kidney [88].

\section{Vasodilator}

Interestingly, in patients with septic shock, local acetylcholine application in the sublingual area completely recovered microcirculation dysfunction when examined using sublingual microscopy [47]. However, in a randomized trial of 70 patients with sepsis, intravenous nitroglycerin did not promote microcirculation when examined using sublingual microscopy [89].

In a study by De Backer et al. [90], the intravenous administration of dobutamine $(5 \mu \mathrm{g} / \mathrm{kg} / \mathrm{min})$ improved sublingual microcirculation in patients with septic shock. Interestingly, this microcirculatory improvement was independent of changes in cardiac output and blood pressure and was closely related to the decrease in lactate concentration. Thus, the microcirculatory effect of dobutamine could not be detected using conventional macrocirculatory parameters.

\section{Fluid administration}

In several previous clinical trials with patients with sepsis, fluid infusion improved the microvascular flow index when measured using sublingual microscopy. In one study, this improvement in microcirculation was similar to the effect of passive leg raising [91]. In another study, fluid resuscitation improved the clinical signs of impaired organ perfusion and microvascular flow index when measured using sublingual microscopy for patients with a microvascular flow index of $<2.6$. However, in patients with baseline microvascular flow index 
values of $>2.6$, there was no improvement in the clinical signs of impaired organ perfusion and microvascular flow index [92]. In another study on patients with sepsis, fluid administration improved microcirculation examined using sublingual microscopy only in the early phase of sepsis [93].

In a prospective randomized trial with 20 patients with sepsis, goal-directed therapy using $6 \%$ hydroxyethyl starch 130/04 showed better microcirculation when examined on sublingual microscopy than when using isotonic saline [94].

\section{Transfusion}

In several previous studies, red blood cell transfusion improved sublingual microvascular density in patients undergoing cardiac surgery $[95,96]$.

Meanwhile, in another study performed in 35 patients with sepsis, although sublingual microcirculation remained unchanged after transfusion, transfusion improved sublingual microcirculation in a subgroup of patients who had impaired microvascular perfusion at baseline [97]. This finding indicates that the effect of transfusion varies significantly according to the microcirculatory status of each individual patient; microcirculatory evaluation may help identify patients who would benefit from transfusion.

\section{Hydrocortisone}

In a previous study, intravenous hydrocortisone improved microcirculation, as evaluated using sublingual microscopy [98]: microcirculatory parameters, such as small vessel density and proportion of perfused vessels, increased after the administration of "stress dose" hydrocortisone (50 mg per 6 h) in 20 patients with septic shock.

\section{THE PRESENT AND FUTURE OF MICROCIRCULATION}

Until now, there has been no reliable and practical intervention that can improve or prevent microcirculatory dysfunction. Most previous studies on interventions to improve microcirculation were small, single-center studies showing inconsistent results [99-105]. Traditional hemodynamic interventions to improve macrocirculation may not improve and may even impair microcirculation. It is possible that some interventions can improve microcirculation.

Even if we establish an intervention that may improve microcirculation, there is one more point to consider. Although the relationship between microcirculatory dysfunction and poor clinical outcome has been well proven in various clinical situations [106-108], it does not necessarily mean that the recovery of microcirculatory dysfunction will improve the clinical outcome.

It could be said that there is a long way to go in this research field. However, considering that a substantial number of patients with microvascular dysfunction experience morbidity and mortality even after the optimization of macro-hemodynamic parameters, establishing an intervention to improve microcirculation will have great clinical impact on critical and perioperative medicine.

\section{CONCLUSIONS}

Traditionally, the hemodynamic management of surgical patients has mainly focused on macrocirculatory parameters, such as cardiac output and blood pressure. However, microcirculatory dysfunction occurs frequently in surgical patients, and both macrocirculation and microcirculation are essential for successful oxygen transport to tissues. Thus, even after achieving sufficient adequate macrocirculatory parameters does not necessarily guarantee for sufficient microcirculatory dysfunction, which is also important to optimize postoperative outcomes. This is still related to postoperative complications. However, unlike traditional macrocirculatory hemodynamic management, there is a lack of research on microcirculatory hemodynamic management, and little is known about how to improve microcirculation. Therefore, future research should focus on effective interventions to recover microcirculation. To determine these interventions, we require a more standardized and practical monitoring tool to evaluate microcirculation in the clinical field.

\section{FUNDING}

None.

\section{CONFLICTS OF INTEREST}

No potential conflict of interest relevant to this article was reported.

\section{DATA AVAILABILITY STATEMENT}

Data sharing is not applicable to this article as no datasets 
were generated or analyzed in the current study.

\section{ORCID}

Karam Nam, https://orcid.org/0000-0002-7384-5325

Yunseok Jeon, https://orcid.org/0000-0001-8686-1124

\section{REFERENCES}

1. Baez S. Microcirculation. Annu Rev Physiol 1977; 39: 391-415.

2. Galley HF, Webster NR. Acidosis and tissue hypoxia in the critically ill: how to measure it and what does it mean. Crit Rev Clin Lab Sci 1999; 36: 35-60.

3. Flower L, Martin D. Management of hypoxaemia in the critically ill patient. Br J Hosp Med (Lond) 2020; 81: 1-10.

4. SRLF Trial Group. Hypoxemia in the ICU: prevalence, treatment, and outcome. Ann Intensive Care 2018; 8: 82. Erratum in: Ann Intensive Care 2019; 9: 10.

5. Pour-Ghaz I, Manolukas T, Foray N, Raja J, Rawal A, Ibebuogu UN, et al. Accuracy of non-invasive and minimally invasive hemodynamic monitoring: where do we stand? Ann Transl Med 2019; 7: 421.

6. Ince C. Hemodynamic coherence and the rationale for monitoring the microcirculation. Crit Care 2015; 19(Suppl 3): S8.

7. Moore JP, Dyson A, Singer M, Fraser J. Microcirculatory dysfunction and resuscitation: why, when, and how. Br J Anaesth 2015; 115: 366-75

8. Miranda M, Balarini M, Caixeta D, Bouskela E. Microcirculatory dysfunction in sepsis: pathophysiology, clinical monitoring, and potential therapies. Am J Physiol Heart Circ Physiol 2016; 311: H24-35.

9. Haase-Fielitz A, Haase M, Bellomo R, Calzavacca P, Spura A, Baraki H, et al. Perioperative hemodynamic instability and fluid overload are associated with increasing acute kidney injury severity and worse outcome after cardiac surgery. Blood Purif 2017; 43: 298-308.

10. De Backer D. Is microcirculatory assessment ready for regular use in clinical practice? Curr Opin Crit Care 2019; 25: 280-4.

11. Flick M, Duranteau J, Scheeren TWL, Saugel B. Monitoring of the sublingual microcirculation during cardiac surgery: current knowledge and future directions. J Cardiothorac Vasc Anesth 2020; 34: 2754-65.

12. Dubin A, Kanoore Edul VS, Caminos Eguillor JF, Ferrara G. Monitoring microcirculation: utility and barriers - a point-ofview review. Vasc Health Risk Manag 2020; 16: 577-89.

13. Groner W, Winkelman JW, Harris AG, Ince C, Bouma GJ, Messmer K, et al. Orthogonal polarization spectral imaging: a new method for study of the microcirculation. Nat Med 1999; 5: 1209-12.

14. Guven G, Hilty MP, Ince C. Microcirculation: physiology, pathophysiology, and clinical application. Blood Purif 2020; 49: 14350.

15. Mathura KR, Bouma GJ, Ince C. Abnormal microcirculation in brain tumours during surgery. Lancet 2001; 358: 1698-9.

16. Goedhart PT, Khalilzada M, Bezemer R, Merza J, Ince C. Sidestream Dark Field (SDF) imaging: a novel stroboscopic LED ring-based imaging modality for clinical assessment of the microcirculation. Opt Express 2007; 15: 15101-14.

17. Aykut G, Veenstra G, Scorcella C, Ince C, Boerma C. Cytocam-IDF (incident dark field illumination) imaging for bedside monitoring of the microcirculation. Intensive Care Med Exp 2015; 3: 40.

18. Ince C, Boerma EC, Cecconi M, De Backer D, Shapiro NI, Duranteau J, et al. Second consensus on the assessment of sublingual microcirculation in critically ill patients: results from a task force of the European Society of Intensive Care Medicine. Intensive Care Med 2018; 44: 281-99.

19. den Uil CA, Bezemer R, Miranda DR, Ince C, Lagrand WK, Hartman M, et al. Intra-operative assessment of human pulmonary alveoli in vivo using Sidestream Dark Field imaging: a feasibility study. Med Sci Monit 2009; 15: MT137-41.

20. Nilsson J, Eriksson S, Blind PJ, Rissler P, Sturesson C. Microcirculation changes during liver resection--a clinical study. Microvasc Res 2014; 94: 47-51.

21. Pérez-Bárcena J, Goedhart P, Ibáñez J, Brell M, García R, Llinás $\mathrm{P}$, et al. Direct observation of human microcirculation during decompressive craniectomy after stroke. Crit Care Med 2011; 39: 1126-9.

22. Tanaka S, Harrois A, Nicolaï C, Flores M, Hamada S, Vicaut E, et al. Qualitative real-time analysis by nurses of sublingual microcirculation in intensive care unit: the MICRONURSE study. Crit Care 2015; 19: 388.

23. Dobbe JG, Streekstra GJ, Atasever B, van Zijderveld R, Ince C. Measurement of functional microcirculatory geometry and velocity distributions using automated image analysis. Med Biol Eng Comput 2008; 46: 659-70.

24. Hilty MP, Guerci P, Ince Y, Toraman F, Ince C. MicroTools enables automated quantification of capillary density and red blood cell velocity in handheld vital microscopy. Commun Biol 2019; $2: 217$.

25. Guay CS, Khebir M, Shiva Shahiri T, Szilagyi A, Cole EE, Simoneau G, et al. Evaluation of automated microvascular flow analysis software AVA 4: a validation study. Intensive Care Med Exp 2021; 9: 15 . 
26. De Backer D, Hollenberg S, Boerma C, Goedhart P, Büchele G, Ospina-Tascon G, et al. How to evaluate the microcirculation: report of a round table conference. Crit Care 2007; 11: R101.

27. Cecconi M, De Backer D, Antonelli M, Beale R, Bakker J, Hofer $\mathrm{C}$, et al. Consensus on circulatory shock and hemodynamic monitoring. Task force of the European Society of Intensive Care Medicine. Intensive Care Med 2014; 40: 1795-815.

28. Gómez H, Torres A, Polanco P, Kim HK, Zenker S, Puyana JC, et al. Use of non-invasive NIRS during a vascular occlusion test to assess dynamic tissue $\mathrm{O}_{2}$ saturation response. Intensive Care Med 2008; 34: 1600-7.

29. De Blasi RA, Palmisani S, Alampi D, Mercieri M, Romano R, Collini S, et al. Microvascular dysfunction and skeletal muscle oxygenation assessed by phase-modulation near-infrared spectroscopy in patients with septic shock. Intensive Care Med 2005; 31: 1661-8.

30. Doerschug KC, Delsing AS, Schmidt GA, Haynes WG. Impairments in microvascular reactivity are related to organ failure in human sepsis. Am J Physiol Heart Circ Physiol 2007; 293: H1065-71.

31. Pareznik R, Knezevic R, Voga G, Podbregar M. Changes in muscle tissue oxygenation during stagnant ischemia in septic patients. Intensive Care Med 2006; 32: 87-92.

32. Creteur J, Carollo T, Soldati G, Buchele G, De Backer D, Vincent JL. The prognostic value of muscle $\mathrm{StO}_{2}$ in septic patients. Intensive Care Med 2007; 33: 1549-56.

33. Kim TK, Cho YJ, Min JJ, Murkin JM, Bahk JH, Hong DM, et al. Microvascular reactivity and clinical outcomes in cardiac surgery. Crit Care 2015; 19: 316.

34. Humeau A, Steenbergen W, Nilsson H, Strömberg T. Laser Doppler perfusion monitoring and imaging: novel approaches. Med Biol Eng Comput 2007; 45: 421-35.

35. Knotzer H, Hasibeder WR. Microcirculatory function monitoring at the bedside--a view from the intensive care. Physiol Meas 2007; 28: R65-86.

36.Nilsson GE, Tenland T, Ake Öberg P. Laser-Doppler methods for the assessment of microcirculatory blood flow. Trans Inst Meas Control 1982; 4: 109-12.

37. Bonner R, Nossal R. Model for laser Doppler measurements of blood flow in tissue. Appl Opt 1981; 20: 2097-107.

38. Haisjackl M, Hasibeder W, Klaunzer S, Altenberger H, Koller W. Diminished reactive hyperemia in the skin of critically ill patients. Crit Care Med 1990; 18: 813-8.

39. Knotzer H, Pajk W, Dünser MW, Maier S, Mayr AJ, Ritsch N, et al. Regional microvascular function and vascular reactivity in patients with different degrees of multiple organ dysfunction syndrome. Anesth Analg 2006; 102: 1187-93.
40. Young JD, Cameron EM. Dynamics of skin blood flow in human sepsis. Intensive Care Med 1995; 21: 669-74.

41. Luckner G, Dünser MW, Stadlbauer KH, Mayr VD, Jochberger S, Wenzel V, et al. Cutaneous vascular reactivity and flow motion response to vasopressin in advanced vasodilatory shock and severe postoperative multiple organ dysfunction syndrome. Crit Care 2006; 10: R40.

42. Hernandez G, Bruhn A, Ince C. Microcirculation in sepsis: new perspectives. Curr Vasc Pharmacol 2013; 11: 161-9.

43. Creteur J, De Backer D, Sakr Y, Koch M, Vincent JL. Sublingual capnometry tracks microcirculatory changes in septic patients. Intensive Care Med 2006; 32: 516-23.

44. Mesquida J, Borrat X, Lorente JA, Masip J, Baigorri F. [Objectives of hemodynamic resuscitation]. Med Intensiva 2011 35: 499508. Spanish.

45. Mahmood A, Gosling P, Barclay R, Kilvington F, Vohra R. Splanchnic microcirculation protection by hydroxyethyl starches during abdominal aortic aneurysm surgery. Eur J Vasc Endovasc Surg 2009; 37: 319-25.

46. Leppikangas H, Tenhunen JJ, Lindgren L, Salenius JP, Ruokonen E. Effects of levosimendan on indocyanine green plasma disappearance rate and the gastric mucosal-arterial $\mathrm{pCO}_{2}$ gradient in abdominal aortic aneurysm surgery. Acta Anaesthesiol Scand 2008; 52: 785-92.

47. De Backer D, Creteur J, Preiser JC, Dubois MJ, Vincent JL. Microvascular blood flow is altered in patients with sepsis. Am J Respir Crit Care Med 2002; 166: 98-104.

48. Trzeciak S, Dellinger RP, Parrillo JE, Guglielmi M, Bajaj J, Abate NL, et al. Early microcirculatory perfusion derangements in patients with severe sepsis and septic shock: relationship to hemodynamics, oxygen transport, and survival. Ann Emerg Med 2007; 49: 88-98, 98.e1-2.

49. Spanos A, Jhanji S, Vivian-Smith A, Harris T, Pearse RM. Early microvascular changes in sepsis and severe sepsis. Shock 2010; 33: 387-91.

50. Sakr Y, Dubois MJ, De Backer D, Creteur J, Vincent JL. Persistent microcirculatory alterations are associated with organ failure and death in patients with septic shock. Crit Care Med 2004; 32: 1825-31.

51. Trzeciak S, McCoy JV, Phillip Dellinger R, Arnold RC, Rizzuto M, Abate NL, et al. Early increases in microcirculatory perfusion during protocol-directed resuscitation are associated with reduced multi-organ failure at $24 \mathrm{~h}$ in patients with sepsis. Intensive Care Med 2008; 34: 2210-7.

52. De Backer D, Ortiz JA, Salgado D. Coupling microcirculation to systemic hemodynamics. Curr Opin Crit Care 2010; 16: 250-4.

53. Hernandez G, Boerma EC, Dubin A, Bruhn A, Koopmans M, 
Edul VK, et al. Severe abnormalities in microvascular perfused vessel density are associated to organ dysfunctions and mortality and can be predicted by hyperlactatemia and norepinephrine requirements in septic shock patients. J Crit Care 2013 28: 538.e9-14.

54. Rivers E, Nguyen B, Havstad S, Ressler J, Muzzin A, Knoblich B, et al. Early goal-directed therapy in the treatment of severe sepsis and septic shock. N Engl J Med 2001; 345: 1368-77.

55. Weiss SL, Peters MJ, Alhazzani W, Agus MSD, Flori HR, Inwald DP, et al. Surviving sepsis campaign international guidelines for the management of septic shock and sepsis-associated organ dysfunction in children. Intensive Care Med 2020; 46(Suppl 1): 10-67.

56. ProCESS Investigators, Yealy DM, Kellum JA, Huang DT, Barnato $\mathrm{AE}$, Weissfeld LA, et al. A randomized trial of protocol-based care for early septic shock. N Engl J Med 2014; 370: 1683-93.

57. ARISE Investigators; ANZICS Clinical Trials Group, Peake SL, Delaney A, Bailey M, Bellomo R, et al. Goal-directed resuscitation for patients with early septic shock. N Engl J Med 2014; 371: 1496-506

58. Mouncey PR, Osborn TM, Power GS, Harrison DA, Sadique MZ, Grieve RD, et al. Protocolised Management In Sepsis (ProMISe): a multicentre randomised controlled trial of the clinical effectiveness and cost-effectiveness of early, goal-directed, protocolised resuscitation for emerging septic shock. Health Technol Assess 2015; 19: i-xxv, 1.

59. Asfar P, Meziani F, Hamel JF, Grelon F, Megarbane B, Anguel N, et al. High versus low blood-pressure target in patients with septic shock. N Engl J Med 2014; 370: 1583-93.

60. Chalkias A, Papagiannakis N, Mavrovounis G, Kolonia K, Mermiri M, Pantazopoulos I, et al. Sublingual microcirculatory alterations during the immediate and early postoperative period: a systematic review and meta-analysis. Clin Hemorheol Microcirc 2021 doi: 10.3233/CH-211214. [Epub ahead of print].

61. Nakatsuka M. Assessment of gut mucosal perfusion and colonic tissue blood flow during abdominal aortic surgery with gastric tonometry and laser Doppler flowmetry. Vasc Endovascular Surg 2002; 36: 193-8.

62. Jhanji S, Lee C, Watson D, Hinds C, Pearse RM. Microvascular flow and tissue oxygenation after major abdominal surgery: association with post-operative complications. Intensive Care Med 2009; 35: 671-7.

63. Yeh YC, Wang MJ, Chao A, Ko WJ, Chan WS, Fan SZ, et al. Correlation between early sublingual small vessel density and late blood lactate level in critically ill surgical patients. J Surg Res 2013; 180: 317-21.

64. Jongman RM, Zijlstra JG, Kok WF, van Harten AE, Mariani MA,
Moser J, et al. Off-pump CABG surgery reduces systemic inflammation compared with on-pump surgery but does not change systemic endothelial responses: a prospective randomized study. Shock 2014; 42: 121-8.

65. Molitoris BA, Sandoval R, Sutton TA. Endothelial injury and dysfunction in ischemic acute renal failure. Crit Care Med 2002; 30(5 Suppl): S235-40.

66. Onorati F, Rubino AS, Nucera S, Foti D, Sica V, Santini F, et al. Off-pump coronary artery bypass surgery versus standard linear or pulsatile cardiopulmonary bypass: endothelial activation and inflammatory response. Eur J Cardiothorac Surg 2010; 37: 897-904.

67. Paparella D, Yau TM, Young E. Cardiopulmonary bypass induced inflammation: pathophysiology and treatment. An update. Eur J Cardiothorac Surg 2002; 21: 232-44.

68. Raja SG, Berg GA. Impact of off-pump coronary artery bypass surgery on systemic inflammation: current best available evidence. J Card Surg 2007; 22: 445-55.

69. Kourliouros A, Valencia O, Phillips SD, Collinson PO, van Besouw JP, Jahangiri M. Low cardiopulmonary bypass perfusion temperatures are associated with acute kidney injury following coronary artery bypass surgery. Eur J Cardiothorac Surg 2010; 37: 704-9.

70. Presta P, Onorati F, Fuiano L, Mastroroberto P, Santarpino G, Tozzo C, et al. Can pulsatile cardiopulmonary bypass prevent perioperative renal dysfunction during myocardial revascularization in elderly patients? Nephron Clin Pract 2019; 111: c22935 .

71. O’Dwyer C, Woodson LC, Conroy BP, Lin CY, Deyo DJ, Uchida $\mathrm{T}$, et al. Regional perfusion abnormalities with phenylephrine during normothermic bypass. Ann Thorac Surg 1997; 63: 72835 .

72. Huybregts RA, de Vroege R, Jansen EK, van Schijndel AW, Christiaans HM, van Oeveren W. The association of hemodilution and transfusion of red blood cells with biochemical markers of splanchnic and renal injury during cardiopulmonary bypass. Anesth Analg 2009; 109: 331-9.

73. De Backer D, Creteur J, Dubois MJ, Sakr Y, Vincent JL. Microvascular alterations in patients with acute severe heart failure and cardiogenic shock. Am Heart J 2004; 147: 91-9.

74. den Uil CA, Caliskan K, Lagrand WK, van der Ent M, Jewbali LS, van Kuijk JP, et al. Dose-dependent benefit of nitroglycerin on microcirculation of patients with severe heart failure. Intensive Care Med 2009; 35: 1893-9.

75. Jung C, Ferrari M, Rödiger C, Fritzenwanger M, Goebel B, Lauten A, et al. Evaluation of the sublingual microcirculation in cardiogenic shock. Clin Hemorheol Microcirc 2009; 42: 141-8. 
76. De Backer D, Dubois MJ, Schmartz D, Koch M, Ducart A, Barvais L, et al. Microcirculatory alterations in cardiac surgery: effects of cardiopulmonary bypass and anesthesia. Ann Thorac Surg 2009; 88: 1396-403.

77. Bauer A, Kofler S, Thiel M, Eifert S, Christ F. Monitoring of the sublingual microcirculation in cardiac surgery using orthogonal polarization spectral imaging: preliminary results. Anesthesiology 2007; 107: 939-45.

78. Maier S, Hasibeder WR, Hengl C, Pajk W, Schwarz B, Margreiter J, et al. Effects of phenylephrine on the sublingual microcirculation during cardiopulmonary bypass. Br J Anaesth 2009; 102: 485-91.

79. Elbers PW, Ozdemir A, van Iterson M, van Dongen EP, Ince C. Microcirculatory imaging in cardiac anesthesia: ketanserin reduces blood pressure but not perfused capillary density. J Cardiothorac Vasc Anesth 2009; 23: 95-101.

80. Koning NJ, Vonk AB, Meesters MI, Oomens T, Verkaik M, Jansen EK, et al. Microcirculatory perfusion is preserved during off-pump but not on-pump cardiac surgery. J Cardiothorac Vasc Anesth 2014; 28: 336-41.

81. den Uil CA, Lagrand WK, Spronk PE, van Domburg RT, Hofland J, Lüthen C, et al. Impaired sublingual microvascular perfusion during surgery with cardiopulmonary bypass: a pilot study. J Thorac Cardiovasc Surg 2008; 136: 129-34.

82. Edul VS, Enrico C, Laviolle B, Vazquez AR, Ince C, Dubin A. Quantitative assessment of the microcirculation in healthy volunteers and in patients with septic shock. Crit Care Med 2012; 40: 1443-8.

83. Tachon G, Harrois A, Tanaka S, Kato H, Huet O, Pottecher J, et al. Microcirculatory alterations in traumatic hemorrhagic shock. Crit Care Med 2014; 42: 1433-41.

84. Lima A, Jansen TC, van Bommel J, Ince C, Bakker J. The prognostic value of the subjective assessment of peripheral perfusion in critically ill patients. Crit Care Med 2009; 37: 934-8.

85. Dubin A, Pozo MO, Casabella CA, Pálizas F Jr, Murias G, Moseinco MC, et al. Increasing arterial blood pressure with norepinephrine does not improve microcirculatory blood flow: a prospective study. Crit Care 2009; 13: R92.

86. LeDoux D, Astiz ME, Carpati CM, Rackow EC. Effects of perfusion pressure on tissue perfusion in septic shock. Crit Care Med 2000; 28: 2729-32.

87. Nakajima Y, Baudry N, Duranteau J, Vicaut E. Effects of vasopressin, norepinephrine, and L-arginine on intestinal microcirculation in endotoxemia. Crit Care Med 2006; 34: 1752-7.

88. Redfors B, Bragadottir G, Sellgren J, Swärd K, Ricksten SE. Effects of norepinephrine on renal perfusion, filtration and oxygenation in vasodilatory shock and acute kidney injury. Inten- sive Care Med 2011; 37: 60-7.

89. Boerma EC, Koopmans M, Konijn A, Kaiferova K, Bakker AJ, van Roon EN, et al. Effects of nitroglycerin on sublingual microcirculatory blood flow in patients with severe sepsis/septic shock after a strict resuscitation protocol: a double-blind randomized placebo controlled trial. Crit Care Med 2010; 38: 93 100.

90. De Backer D, Creteur J, Dubois MJ, Sakr Y, Koch M, Verdant C, et al. The effects of dobutamine on microcirculatory alterations in patients with septic shock are independent of its systemic effects. Crit Care Med 2006; 34: 403-8.

91. Pottecher J, Deruddre S, Teboul JL, Georger JF, Laplace C, Benhamou D, et al. Both passive leg raising and intravascular volume expansion improve sublingual microcirculatory perfusion in severe sepsis and septic shock patients. Intensive Care Med 2010; 36: 1867-74

92. Pranskunas A, Koopmans M, Koetsier PM, Pilvinis V, Boerma EC. Microcirculatory blood flow as a tool to select ICU patients eligible for fluid therapy. Intensive Care Med 2013; 39: 612-9.

93. Ospina-Tascon G, Neves AP, Occhipinti G, Donadello K, Büchele G, Simion D, et al. Effects of fluids on microvascular perfusion in patients with severe sepsis. Intensive Care Med 2010; 36: 949-55.

94. Dubin A, Pozo MO, Casabella CA, Murias G, Pálizas F Jr, Moseinco MC, et al. Comparison of $6 \%$ hydroxyethyl starch $130 / 0.4$ and saline solution for resuscitation of the microcirculation during the early goal-directed therapy of septic patients. J Crit Care 2010 25: 659.e1-8.

95. Atasever B, van der Kuil M, Boer C, Vonk A, Schwarte L, Girbes $\mathrm{AR}$, et al. Red blood cell transfusion compared with gelatin solution and no infusion after cardiac surgery: effect on microvascular perfusion, vascular density, hemoglobin, and oxygen saturation. Transfusion 2012; 52: 2452-8.

96. Yuruk K, Almac E, Bezemer R, Goedhart P, de Mol B, Ince C. Blood transfusions recruit the microcirculation during cardiac surgery. Transfusion 2011; 51: 961-7.

97. Sakr Y, Chierego M, Piagnerelli M, Verdant C, Dubois MJ, Koch $\mathrm{M}$, et al. Microvascular response to red blood cell transfusion in patients with severe sepsis. Crit Care Med 2007; 35: 1639-44.

98. Büchele GL, Silva E, Ospina-Tascón GA, Vincent JL, De Backer D. Effects of hydrocortisone on microcirculatory alterations in patients with septic shock. Crit Care Med 2009; 37: 1341-7.

99. Vollmer C, Weber APM, Wallenfang M, Hoffmann T, Mettler-Altmann T, Truse R, et al. Melatonin pretreatment improves gastric mucosal blood flow and maintains intestinal barrier function during hemorrhagic shock in dogs. Microcirculation 2017; 24: e12345. 
100. Dumbarton TC, Maxan A, Farah N, Sharawy N, Zhou J, Nantais J, et al. Tetrahydrobiopterin improves microcirculation in experimental sepsis. Clin Hemorheol Microcirc 2017; 67: 1524.

101. Vollmer C, Schwartges I, Swertz M, Beck C, Bauer I, Picker O. Hypothermia improves oral and gastric mucosal microvascular oxygenation during hemorrhagic shock in dogs. Oxid Med Cell Longev 2013; 2013: 589606.

102. Marik PE, Zaloga GP. Hypothermia and cytokines in septic shock. Norasept II Study Investigators. North American study of the safety and efficacy of murine monoclonal antibody to tumor necrosis factor for the treatment of septic shock. Intensive Care Med 2000; 26: 716-21.

103. Itenov TS, Johansen ME, Bestle M, Thormar K, Hein L, Gyldensted L, et al. Induced hypothermia in patients with septic shock and respiratory failure (CASS): a randomised, controlled, open-label trial. Lancet Respir Med 2018; 6: 183-
92.

104. Harrois A, Dupic L, Duranteau J. Targeting the microcirculation in resuscitation of acutely unwell patients. Curr Opin Crit Care 2011; 17: 303-7.

105. Shapiro NI, Angus DC. A review of therapeutic attempts to recruit the microcirculation in patients with sepsis. Minerva Anestesiol 2014; 80: 225-35.

106. Armstrong R, De Maria GL, Scarsini R, Banning AP. Assessing and managing coronary microcirculation dysfunction in acute ST-segment elevation myocardial infarction. Expert Rev Cardiovasc Ther 2019; 17: 111-26.

107. den Uil CA, Lagrand WK, van der Ent M, Jewbali LS, Cheng JM, Spronk PE, et al. Impaired microcirculation predicts poor outcome of patients with acute myocardial infarction complicated by cardiogenic shock. Eur Heart J 2010; 31: 3032-9.

108. Ince C, De Backer D, Mayeux PR. Microvascular dysfunction in the critically Ill. Crit Care Clin 2020; 36: 323-31. 